\title{
Detrital production in Nova Scotian kelp beds: patterns and processes
}

\author{
Kira A. Krumhansl ${ }^{1, *}$, Robert E. Scheibling ${ }^{1}$ \\ ${ }^{1}$ Department of Biology, Dalhousie University, Halifax, Nova Scotia B3H 4J1, Canada
}

\begin{abstract}
Connectivity via the transport of detrital material from areas of high to low productivity may be an important determinant of secondary productivity and biodiversity in receiving communities. On the Atlantic coast of Nova Scotia, detritus exported from subtidal kelp beds contributes to food webs in communities inhabiting deeper waters offshore. To estimate the amount of energy available via this pathway, we measured rates of detrital production via erosion of kelp blades in kelp beds at 5 sites varying in wave exposure. Specifically, we measured productivity and erosion of the 2 dominant species of kelp, Laminaria digitata and Saccharina longicruris, over 16 mo. We also examined the effect of environmental and biological factors on erosion rates, including temperature, wave exposure, grazing by snails and cover by the invasive bryozoan Membranipora membranacea. We observed clear seasonal and spatial patterns in productivity, with the highest production in spring. Erosion rate was highly variable across sites and seasons, and was strongly related to the cover of $M$. membranacea and the intensity of snail grazing at the distal end of kelp blades. Both factors cause tissue degradation, abrasions and perforations that weaken blades. Erosion rate was also positively related to water temperature and site exposure. Annual detrital production from the erosion of kelp blades increased linearly with kelp bed biomass, and ranged from 0.5 to $1.71 \mathrm{~kg}$ dry weight $\mathrm{m}^{-2}\left(150-513 \mathrm{~g} \mathrm{C} \mathrm{m}^{-2}\right)$ across sites. These rates equal or exceed annual phytoplankton production off the Atlantic coast of Nova Scotia and estimates of detrital production in seagrass beds in North America.
\end{abstract}

KEY WORDS: Detritus · Grazing $\cdot$ Invasive species $\cdot$ Kelp bed $\cdot$ Laminaria digitata $\cdot$ Membranipora membranacea $\cdot$ Productivity $\cdot$ Saccharina longicruris

\section{INTRODUCTION}

The importance of connectivity between adjacent habitats in determining the structure of populations and communities is a central theme in contemporary marine ecological research (Polis \& Hurd 1996, Huxel \& McCann 1998, Nakano \& Murakami 2001). Studies of connectivity in marine systems have focused largely on mobile species (Lundberg \& Moberg 2003) or on widely dispersing larval stages (Lipcius et al. 2008). The role of energy exchange in the form of detritus in influencing patterns of abundance and productivity in recipient communities (Duggins et al. 1989, Polis \& Hurd 1996, Polis et al. 1997) has received less attention. Studies that have explored this linkage provide evidence to suggest that exchange of detrital material may be the main factor driving population and community structure in areas adjacent to productive macroalgal beds. For example, invertebrate populations in intertidal habitats adjacent to subtidal kelp beds have greater secondary productivity than those in areas without a kelp subsidy (Duggins \& Simenstad 1989, Bustamante et al. 1995, Bustamante \& Branch 1996). This linkage is particularly strong when extremely productive ecosystems are adjacent to less productive ones (Polis \& Hurd 1996), and where imported detritus serves as a primary source of food or habitat (Lenanton et al. 1982, Vetter 1998, Vetter \& Dayton 1999, Hyndes \& Lavery 2005). 
The interaction between native and introduced species is another area of expanding interest and concern among marine ecologists and resource managers, as evidence of the negative impacts of biological invasions accumulates (Thomsen et al. 2009, Sorte et al. 2010). This research has primarily addressed the direct effects of introductions on native populations and the resulting changes in biodiversity and ecosystem function (Eastwood et al. 2007, Galil 2007, Schaffelke \& Hewitt 2007). Indirect effects on the dynamics of material and energy exchange between invaded and adjacent native communities are largely unknown.

Kelp ecosystems are amongst the most productive in the world (Mann 1972a, Smith 1988). In Nova Scotia, Canada, kelp beds often are located next to sea urchin barrens, characterized by low productivity and coralline-algal-dominated assemblages (Chapman 1981, Mann 1982, Scheibling et al. 1999). The faunal assemblages that inhabit these barrens (Balch \& Scheibling 2000, Knip \& Scheibling 2007) and adjacent sedimentary habitats in deeper waters (Kenchington et al. 2006) may depend largely on allochthonous inputs from shallow algal beds, as has been observed for deep-water systems elsewhere (Lawson et al. 1993, Vetter 1995), although this connection remains unexplored in the Northwest Atlantic.

Kelp beds on the Atlantic coast of Nova Scotia are highly dynamic. Phase shifts between productive kelp beds and urchin barrens occur on a decadal time scale, driven by fluctuations in the abundance of the sea urchin Strongylocentrotus droebachiensis (Miller 1985, Scheibling et al. 1999, Lauzon-Guay \& Scheibling 2007). The introduction of the epiphytic bryozoan Membranipora membranacea, which encrusts kelp blades, has resulted in several large-scale defoliation events since 1993 (Scheibling \& Gagnon 2006, Saunders \& Metaxas 2008). A reduction in kelp biomass, due to the combined effects of urchin grazing and bryozoan-mediated defoliation, likely affects the dynamics of detrital subsidies to adjacent communities.

Although kelp productivity has been measured extensively off Nova Scotia (Mann 1972a, Chapman \& Craigie 1977, Gerard \& Mann 1979, Smith 1988), the rate of detrital production from kelp assemblages has not been quantified. Some estimates have been obtained through indirect measurements such as productivity/biomass ratios (Mann 1972a, Smith 1988), or from models of kelp carbon budgets by subtracting grazing rates from kelp productivity (Hatcher et al. 1977, Newell et al. 1982). Wave exposure (Gerard \& Mann 1979), nutrients (Chapman \& Craigie 1977) and temperature (Mann 1972a) are known to affect rates of kelp production in Nova Scotia, but factors regulating rates of detrital production remain poorly understood. Wave exposure is expected to play an important role, as large masses of kelp are deposited on beaches exposed to high wave action (Orr et al. 2005). Temperature is linked to tissue degradation in kelps (Rothäusler et al. 2009), and therefore is likely to increase erosion of blades. Biological factors that weaken kelp blades, such as encrustation by Membranipora membranacea (Dixon et al. 1981) and grazing by snails (mainly Lacuna vincta; Johnson \& Mann 1986) also are expected to influence detrital production.

In the present study, we provide direct estimates of the rate of detrital production from subtidal kelp beds by measuring the erosion and production of individual kelp blades over a seasonal cycle at various sites along the Atlantic coast of Nova Scotia near Halifax. The ratio of erosion $(E)$ to productivity $(P)(E: P)$ was calculated as an indication of whether kelp beds are increasing $(E: P<1)$ or decreasing $(>1)$ in biomass. Kelp population density and biomass were measured during each sampling period at each site and were used to estimate erosion per unit area for the portion of the population measured from individual rates. We concurrently measured a suite of physical and biological factors, including temperature, wave exposure, grazing damage by snails and encrustation by Membranipora membranacea. We predicted that erosion of kelp blades would increase with each of these factors. Identifying the main factors driving rates of detrital production aids in understanding how natural and humanmediated environmental variation affects energy export from subtidal kelp beds.

\section{MATERIALS AND METHODS}

Study areas. The present study was conducted at 5 sites along the central region of the Atlantic coast of Nova Scotia, from the western shore of St. Margaret's Bay to the western head of Halifax Harbour (Fig. 1). Sites were selected to represent a range of wave exposures, and the presence or absence of Membranipora membranacea (Table 1). Splitnose Point was selected as the most exposed site and because it experiences moderate to high encrustation by $M$. membranacea in late summer to fall. Duncan's Cove Exposed is located $\sim 3 \mathrm{~km}$ northeast of Splitnose Point within a channel between an island and the mainland. This site was selected because it experiences moderate to high levels of wave action. Duncan's Cove Exposed is more protected than Splitnose Point and contains a mix of ledges and small to large boulders. Duncan's Cove Protected is located $\sim 0.25 \mathrm{~km}$ inshore of the exposed site and is protected from wave action, with kelps growing on small to medium-sized boulders. The Duncan's Cove sites were selected because $M$. membranacea rarely occurs on kelp in this area. Cranberry 


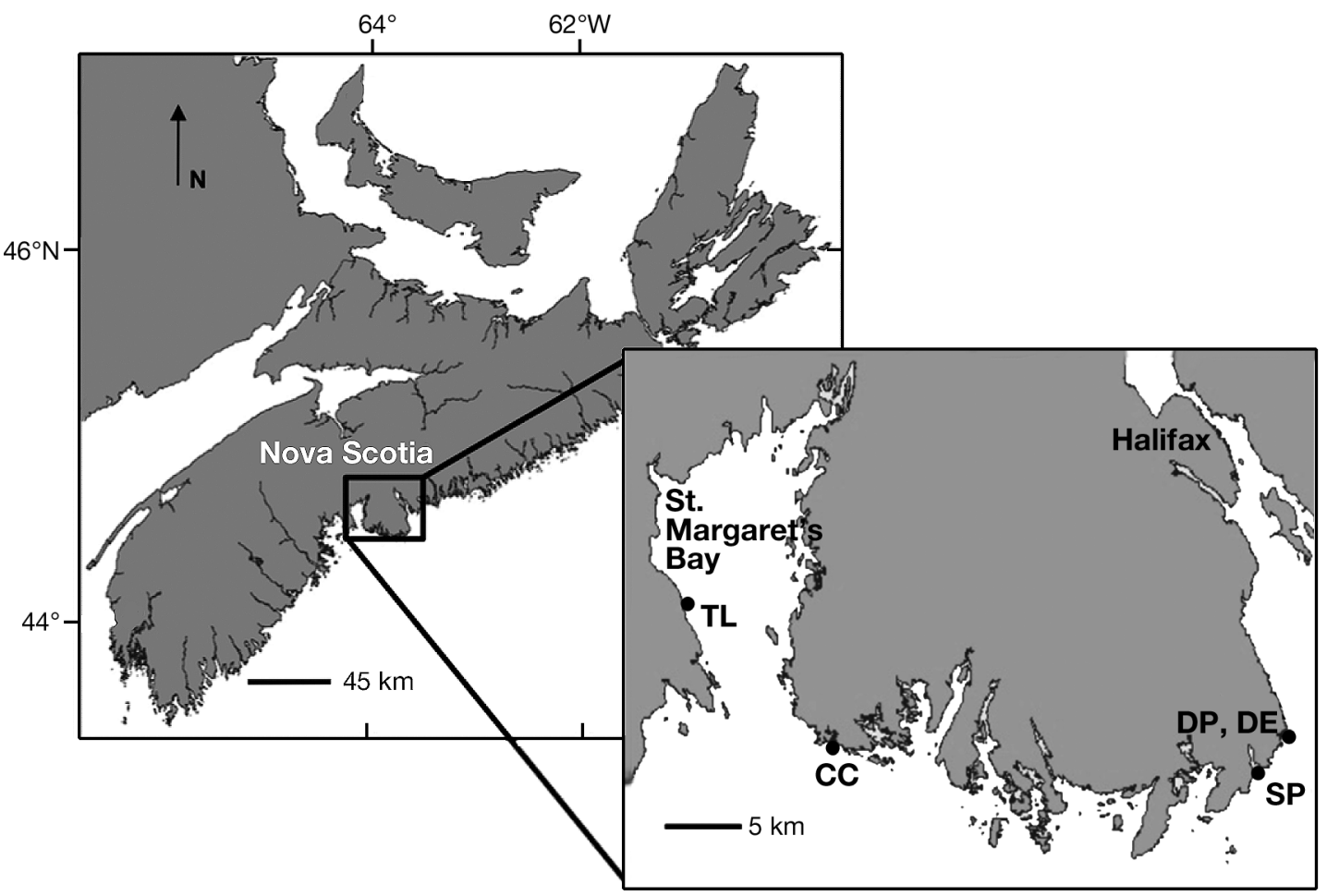

Fig. 1. Study site locations off the Atlantic coast of Nova Scotia, Canada. Inset shows a close-up of the area encompassing study sites. CC: Cranberry Cove; DE: Duncan's Cove Exposed; DP: Duncan's Cove Protected; SP: Splitnose Point; TL: The Lodge

Cove is located $\sim 30 \mathrm{~km}$ southwest of Splitnose Point, and was selected as a low to moderate exposed site. Cranberry Cove contains sparse stands of kelp mixed with the invasive green alga Codium fragile growing on small boulders and large rock outcroppings. M. membranacea also rarely occurs at this site. The Lodge is a low to moderate exposed site located $\sim 11 \mathrm{~km}$ northwest of Cranberry Cove on the western shore of
St. Margaret's Bay. This site was selected because kelp density was low at the start of the study following declines in kelp canopy cover ( $40 \%)$ following a high infestation of M. membranacea in fall 2006 (Saunders \& Metaxas 2008). Measurements of individuals and populations of kelp were taken at 4 to $6 \mathrm{~m}$ depth at all sites, where Saccharina longicruris and Laminaria digitata were the dominant canopy-forming kelps.

Table 1. Location and physical and biological characteristics of the 5 study sites. Kelps are Laminaria digitata and Saccharina longicruris. The last column indicates whether Membranipora membranacea grows epiphytically on kelps at each study site

\begin{tabular}{|c|c|c|c|c|c|}
\hline Site & Lat/Long & Substratum & Exposure & $\begin{array}{l}\text { Dominant } \\
\text { algae }\end{array}$ & $\begin{array}{c}\text { Membranipora } \\
\text { membranacea }\end{array}$ \\
\hline Splitnose Point & $\begin{array}{l}44^{\circ} 28^{\prime} 38.45^{\prime \prime} \mathrm{N} \\
63^{\circ} 32^{\prime} 48.21^{\prime \prime} \mathrm{W}\end{array}$ & Ledges & High, SSE & $\begin{array}{c}\text { Kelps, } \\
\text { Desmarestia spp. }\end{array}$ & Yes \\
\hline $\begin{array}{l}\text { Duncan's Cove } \\
\text { Exposed }\end{array}$ & $\begin{array}{l}44^{\circ} 29^{\prime} 50.22^{\prime \prime} \mathrm{N} \\
63^{\circ} 31^{\prime} 24.26^{\prime \prime} \mathrm{W}\end{array}$ & $\begin{array}{l}\text { Channel between } \\
\text { island and mainland, } \\
\text { with boulders }\end{array}$ & Moderate, SE & Kelps & No \\
\hline $\begin{array}{l}\text { Duncan's Cove } \\
\text { Protected }\end{array}$ & $\begin{array}{l}44^{\circ} 29^{\prime} 52.53^{\prime \prime} \mathrm{N} \\
63^{\circ} 31^{\prime} 34.99^{\prime \prime} \mathrm{W}\end{array}$ & Small boulders & Low, E & Kelps & No \\
\hline The Lodge & $\begin{array}{l}44^{\circ} 33^{\prime} 32.98^{\prime \prime} \mathrm{N} \\
64^{\circ} 01^{\prime} 56.75^{\prime \prime} \mathrm{W}\end{array}$ & $\begin{array}{l}\text { Small boulders } \\
\text { and sand }\end{array}$ & $\begin{array}{c}\text { Low to moderate, } \\
\text { NNE }\end{array}$ & $\begin{array}{l}\text { Kelps, Chondrus } \\
\text { crispus, Fucus spp., } \\
\text { Desmarestia spp. }\end{array}$ & Yes \\
\hline Cranberry Cove & $\begin{array}{l}44^{\circ} 30^{\prime} 0.31^{\prime \prime} \mathrm{N} \\
63^{\circ} 55^{\prime} 22.71^{\prime \prime} \mathrm{W}\end{array}$ & $\begin{array}{l}\text { Boulders and sand, } \\
\text { rocky outcrops }\end{array}$ & $\begin{array}{c}\text { Low to moderate, } \\
\text { SW }\end{array}$ & $\begin{array}{l}\text { Kelps, Fucus spp., } \\
\text { Desmarestia spp. }\end{array}$ & No \\
\hline
\end{tabular}


Productivity and erosion. Productivity and erosion of kelps were measured using SCUBA during 6 sampling periods: July 2008, September 2008 and 2009, November 2008, February 2009 and May 2009. Measurements were taken at all 5 sites during the July, September and May sampling periods, but logistical constraints of winter sampling limited February measurements to 3 sites (Splitnose Point, Duncan's Cove Protected and Cranberry Cove). Measurement in November were taken only at the 2 sites (Splitnose Point and The Lodge) where Membranipora membraneacea commonly occurred on kelps, to capture the period of peak abundance of the bryozoan. Growth and erosion of Saccharina longicruris was measured at all sites and sampling periods, whereas Laminaria digitata was measured at all sites and periods except Cranberry Cove (all periods) and Duncan's Cove Protected (July 2008), where this species was not particularly abundant. During each sampling period, 10-20 thalli of each species were haphazardly selected within a representative stand of kelp at each site and individually labeled with a numbered tag. Only thalli of total length $>30 \mathrm{~cm}$ for L. digitata and $>50 \mathrm{~cm}$ for $S$. longicruris were selected. Due to logistical constraints, sites could not be measured concurrently. Therefore, sampling periods differed by 1 to 2 wk across sites during each sampling month.

Growth and productivity were measured in situ using a modified hole-punch method after Tala \& Edding (2005). A slightly different procedure was used for Laminaria digitata than Saccharina longicruris because of morphological differences between species. S. longicruris has a single blade, whereas L. digitata has a large broad blade that splits into smaller 'digits' near the proximal end. Therefore, a single hole was punched at $10 \mathrm{~cm}$ above the base of the blade in $S$. longicruris, whereas 3 holes were punched in L. digitata: one at $10 \mathrm{~cm}$ and another at $20 \mathrm{~cm}$ directly above the base of the blade (defined as the location where the blade is twice the width of the stipe), and a third hole at $20 \mathrm{~cm}$ above the base of the blade on an outer digit (Fig. 2). Multiple holes in L. digitata ensured that blade

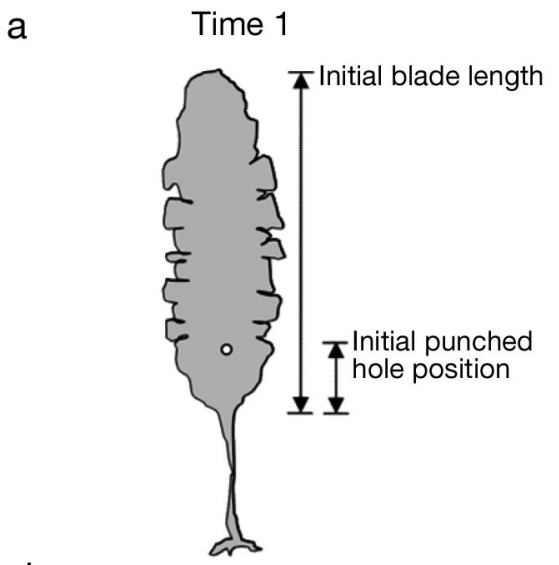

Time 2

b
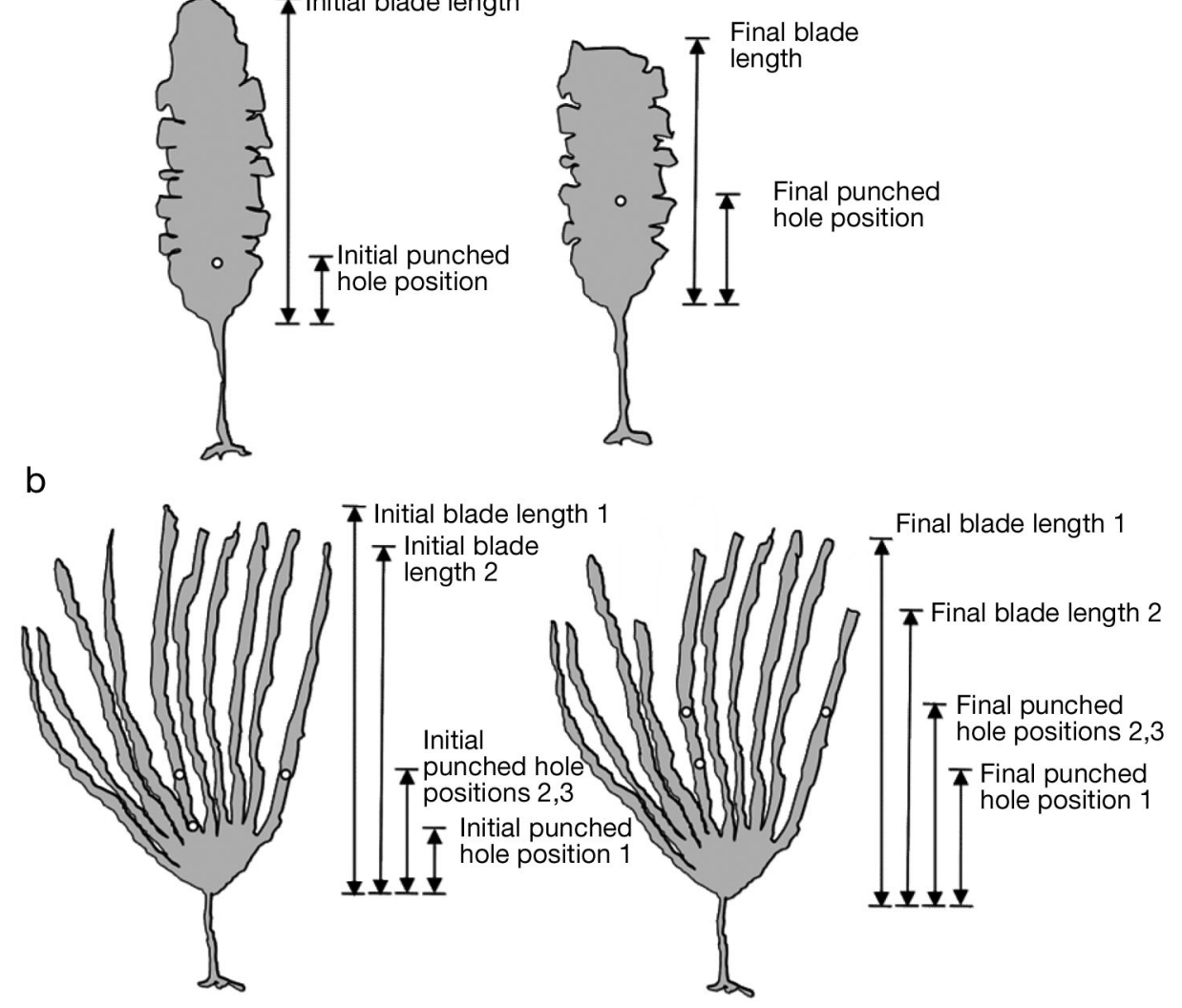

Fig. 2. Diagram showing the hole-punching methods used to measure productivity and erosion in (a) Saccharina longicruris and (b) Laminaria digitata. Diagrams on the left show locations of punched holes and morphometric measurements taken at the start of the sampling period (Time 1); diagrams on the right are the locations of punched holes and measurements taken at the time of collection (Time 2), 2 to $4 \mathrm{wk}$ after Time 1. Multiple holes were punched in thalli of L. digitata to ensure that the same 'digits' were measured at the beginning and end of the measurement period 
length was re-measured on the same digit at the beginning and end of a sampling interval. Stipe length and blade length above each hole were measured with a flexible tape $(1 \mathrm{~cm}$ precision) for each individual.

After 2 to $4 \mathrm{wk}$, marked kelps were collected and returned to the laboratory. Stipe length, growth hole position (as distance from the base of the blade) and final blade length were measured for each individual of Saccharina longicruris. Growth rate of S. longicruris as blade elongation $\left(G_{\mathrm{SL}}, \mathrm{cm} \mathrm{d}^{-1}\right)$ was calculated as:

$$
G_{\mathrm{SL}}=\left(H_{\mathrm{f}}-10\right) t
$$

where $H_{\mathrm{f}}$ is the final growth hole position (cm) and $t$ is the time (d) between initial and final measurements. For Laminaria digitata, stipe length and the positions of each of the 3 holes above the base of the blade were measured. The blade length above each set of holes (central and outer blades) was then measured. Growth rate of L. digitata $\left(\mathrm{G}_{\mathrm{LD}}\right)$ was calculated as:

$$
\left.G_{\mathrm{LD}}=\left\{\left[\left(H_{\mathrm{f} 1}-10\right)+\left(H_{\mathrm{f} 2}-20\right)+H_{\mathrm{f} 3}-20\right)\right] / 3\right\} / \mathrm{t}
$$

where $H_{\mathrm{f} 1}, H_{\mathrm{f} 2}$ and $H_{\mathrm{f} 3}$ are the positions of the 2 inner and 1 outer holes, respectively.

To calculate productivity, blades were cut along their length into 10 to $20 \mathrm{~cm}$ sections, depending on the overall length of the blade, and wet weight was measured for each section. The basal section of the blade (between the base and growth hole) was then dried at $60^{\circ} \mathrm{C}$ for at least $48 \mathrm{~h}$ and weighed. The relationship between dry and wet weight was determined by linear regression for each site and sampling period (Table S1 in the Supplement at www.int-res.com/articles/suppl/ m421p067_supp.pdf). All regression models were significant at $\alpha=0.05$, with $\mathrm{R}^{2}>0.80$. Based on this relationship, dry biomass per unit length of blade $\left(\mathrm{g} \mathrm{cm}^{-1}\right)$ was estimated for the remaining sections of the basal one-third of the blade from wet weight measurements. The measured and estimated dry biomass per unit length in the basal one-third of the blade was then averaged to give $B_{\text {base }}\left(\mathrm{g} \mathrm{cm}^{-1}\right)$. Productivity $\left(\mathrm{g} \mathrm{d}^{-1}\right)$ was calculated as:

$$
P=G \times B_{\text {base }}
$$

where $G$ represents $G_{\mathrm{SL}}$ or $G_{\mathrm{LD}}$ for calculating productivity in Saccharina longicruris and Laminaria digitata, respectively.

For Saccharina longicruris, the loss of tissue from the thallus $(T, \mathrm{~cm})$ was calculated as:

$$
T=\left(L_{\mathrm{i}}+g\right)-L_{\mathrm{f}}
$$

where $L_{\mathrm{i}}$ and $L_{\mathrm{f}}$ are initial and final blade length $(\mathrm{cm})$, respectively, and $g$ is the length of new tissue produced $(\mathrm{cm})$. For Laminaria digitata, $T$ was calculated for the center and outer digits using Eq. (4), and then averaged to generate an estimate of tissue loss from the whole thalli. The relationship between wet and dry weight in the distal section of the thallus for both species was used to estimate the dry biomass per unit length in the distal one-third of the blade $B_{\text {distal }}$ $\left(\mathrm{g} \mathrm{cm}^{-1}\right)$. Erosion rate $\left(\mathrm{g} \mathrm{d}^{-1}\right)$ was then calculated as:

$$
E=(T / t) \times B_{\text {distal }}
$$

The ratio of erosion to productivity $(E: P)$ was then calculated for each individual.

Population measurements. Standing stock biomass and density of both kelp species at each site were measured during all sampling periods. Eight to 9 quadrats of $0.5 \mathrm{~m}^{2}$ were haphazardly placed on the substrate in an area adjacent to the tagged kelp thalli. All individuals of Saccharina longicruris and Laminaria digitata were collected from each quadrat, and individual stipe and total length was measured for each kelp individual $>20 \mathrm{~cm}$ total length. The biomass (as wet weight) of all individuals of each species was weighed for each quadrat using a spring balance (10 g precision).

Detrital production estimates. Daily erosion per unit area $\left(\mathrm{m}^{2}\right)$ was estimated for each site and sampling period based on individual erosion rates. The density of kelps within the size range of thalli measured for erosion and productivity $\left(D_{\mathrm{M}}\right.$, ind. $\left.\mathrm{m}^{2}\right)$ was determined for each site and sampling period from quadrat counts. Erosion rate per unit area $\left(E_{\mathrm{M}}, \mathrm{g} \mathrm{m}^{-2} \mathrm{~d}^{-1}\right)$ for the measured portion of the population was then calculated as:

$$
E_{\mathrm{M}}=E \times D_{\mathrm{M}}
$$

for each species. These values were averaged across sampling periods and multiplied by 365 to estimate annual detrital production for each site $\left(E_{\mathrm{MA}}, \mathrm{kg} \mathrm{m}^{-2}\right.$ $\left.\mathrm{yr}^{-1}\right)$. The proportion $\left(R_{\mathrm{M}}\right)$ of the total population represented by $E_{\mathrm{M}}$ and $E_{\mathrm{MA}}$ was calculated as:

$$
R_{\mathrm{M}}=D_{\mathrm{M}} / D_{\text {Tot }}
$$

where $D_{\text {Tot }}$ is the total density of kelps $>20 \mathrm{~cm}$ in length.

To relate annual detrital production to total kelp biomass, we converted wet biomass measurements averaged across sampling periods for each site and species to dry weight using the ratio of dry to wet weight of marked kelp thalli (including stipe and holdfast). These conversion factors ranged from 0.124 (Splitnose Point) to 0.183 (Cranberry Cove) for Saccharina longicruris, and from 0.158 (Splitnose Point) to 0.162 (Duncan's Cove Protected) for Laminaria digitata.

Physical factors. Seasonal variation in productivity and erosion were examined in relation to temperature and wave action. Temperature was recorded at 10 to 30 min intervals at each site using $\mathrm{HOBO}^{\circledR}$ Tidbit or Pendant Data Loggers (Onset Computer) deployed between 4 and $6 \mathrm{~m}$ depth (Chart Datum). A logger was continuously deployed at The Lodge during the 16 mo 
study; at the other sites, loggers were deployed intermittently. Linear regression was used to determine the relationship between average weekly temperature at The Lodge and each of the other sites individually. These models $\left(R^{2}>0.95, p<0.0001\right)$ were used to extrapolate temperature when direct measurements were not made. Temperature data were unavailable in July 2008 due to equipment malfunction.

A relative wave exposure index (REI) for each site was calculated using a modification of the index by Keddy (1982):

$$
\mathrm{REI}=\sum_{i=1}^{16}\left(V_{i} \times W_{i} \times F_{i}\right)
$$

where $V_{i}$ is average monthly wind speed $\left(\mathrm{km} \mathrm{h}^{-1}\right), W_{i}$ is wind frequency and $F_{i}$ is fetch $(\mathrm{km})$, from the ith direction (north, north northeast, northeast, east northeast, etc., in 16 increments of $22.5^{\circ}$ ). Fetch calculations were site-specific, whereas the same wind data, obtained from Environment Canada's National Climate Data and Information Archive (http://climate.weatheroffice.gc. ca), were used for all sites. Effective fetch is typically used in this exposure index calculation, but our sites are located in semi- or non-enclosed areas, with fetch values of 1000s of $\mathrm{km}$ in some directions, making effective fetch calculations impractical. In these cases, fetch was bounded at $2000 \mathrm{~km}$, the distance within which storms in the Atlantic generate waves that propagate to the coast of Nova Scotia (Hart \& Evans 2001).

Biological factors. Percent cover of Membranipora membranacea on kelp blades was measured at the time of collection for each site and sampling period. Blades were placed under a Plexiglas sheet and photographed using Canon G7 or G10 Powershot digital cameras. Colonies of M. membranacea on the full area of 1 randomly selected side of the blade were outlined using a marker and photographed. To calculate percent cover, the total blade area and the blade area covered by $M$. membranacea were measured using ImageJ (NIH). If blade dimensions exceeded that of the Plexiglas sheet, as was the case for some individuals of Laminaria digitata at Splitnose Point, a randomly selected subsection of the thallus was measured.

The degree of blade damage by snail grazing (primarily Lacuna vincta) was measured for both kelp species to determine its effect on erosion rate. Grazing damage consists of perforations or superficial excavations that do not perforate the blade. Only perforations were measured. Photographs were taken of the complete blade of each individual at the time of final measurement, and the area of grazing holes was measured using image analysis. Erosion primarily occurs in the distal one-third of blades, and grazing intensity in this region is expected to affect erosion. Therefore, distal area grazed was used in later analysis.
Statistical analysis. The effect of site and season (fixed factors) on productivity, erosion rate and the ratio of erosion to productivity $(E: P)$ were examined using 2way ANOVA for seasons when measurements were taken at all sites (July and September 2008 and May and September 2009 for Saccharina longicruris, September 2008 and May and September 2009 for Laminaria digitata). One-way ANOVA was used to compare the effect of season at sites where late fall (November 2008) and winter (February 2009) measurements were taken for both species. Significance values were constrained to $\alpha=0.01$ for 1 -way ANOVA to compensate for inflation of Type I error rates during repeated 1-way ANOVA. Rate data were $\log (x+1)$-transformed and $E: P$ data were $\log (x)$-transformed to meet the assumptions of normality (Shapiro-Wilk test, $\alpha=0.05$ ) and homogeneity of variance (Levene's test, $\alpha=0.05$ ).

To examine factors that influence erosion rate and the E:Pratio, data were averaged across individuals for each species at each site and sampling period for each measurement. We used second-order bias-corrected Akaike's information criterion $\left(\mathrm{AIC}_{\mathrm{c}}\right)$, the values of maximized log-likelihood function and model probabilities to assess the evidence supporting models that predict erosion rate and the $E: P$ ratio, and to assess the relative importance of physical (temperature and site exposure) and biological (percent cover by Membranipora membranacea and percent distal area grazed) factors that may influence these measurements. Using this approach, models can be ranked according to their $\mathrm{AIC}_{\mathrm{C}}$ values, with the lowest $\mathrm{AIC}_{\mathrm{c}}$ value indicating the best model to explain the data. Model probability $\left(w_{i}\right)$ is the probability that a given model is actually the best model (Anderson 2008). We also used log-likelihood values and adjusted $\mathrm{R}^{2}$ values for each model as a means of assessing fit. To examine the relative importance of each factor, we summed the model probabilities of all the models in which each factor appears. Factors with greater summed model probability values are ranked higher, in terms of importance, than factors with lower values (Anderson 2008). All models containing every possible combination of 3 or fewer factors were considered (14 possible models). AIC results decrease in validity if the number of parameters is high in relation to the number of observations (Anderson 2008). Therefore, models with greater than 3 factors were not considered because of the small number of observations. We present only the top 5 models for each measurement. Linear regression analysis was used to determine the coefficient and standard error of each factor in the best model based on $\mathrm{AIC}_{\mathrm{C}}$. July 2008 data were not included in these analyses because temperature and wave data were not available. Variables were not found to be collinear following examination of tolerance values (tolerance < 0.60 ) (Van den Poel \& Lariviere 2004). 


\section{RESULTS}

\section{Physical factors}

The highest temperatures recorded during our sampling periods were in July 2009 (monthly mean: $14.0-16.2^{\circ} \mathrm{C}$ ), and the lowest were in February 2009 $\left(0.6-0.9^{\circ} \mathrm{C}\right.$ ) (Fig. 3). There was little difference in September temperature between $2008\left(12.6-15.2^{\circ} \mathrm{C}\right)$ and $2009\left(12.0-14.4^{\circ} \mathrm{C}\right)$.

Exposure index varied within and across sites with seasonal trends in wind velocity and direction (Fig. 3). Splitnose Point consistently had a higher level of exposure than other sites, whereas Duncan's Cove Protected had the lowest exposure (Fig. 3). Duncan's Cove Exposed, Cranberry Cove and The Lodge had similar levels of exposure across sampling months; the only large difference in exposure between these sites occurred in September 2008, when Duncan's Cove Exposed had a lower exposure than Cranberry Cove and The Lodge (Fig. 3). dance only in fall (September 2009) at Duncan's Cove Exposed (Fig. 4). At Splitnose Point and The Lodge, Saccharina longicruris and Laminaria digitata were encrusted by M. membranacea in fall (September and November 2008, September 2009), and cover was generally highest in November $(S$. longicruris $=41 \%$, L. digitata $=$ $91 \%$ ). Some bryozoan colonies persisted on L. digitata through the winter (February 2009) at Splitnose Point. Percent cover of $M$. membranacea tended to be lower on $S$. longicruris than on $L$. digitata in fall.

Grazing intensity on the distal section of blades of Laminaria digitata was generally highest $(0.2-3.26 \%$ of the distal area grazed) in fall (September and November 2008, September 2009) and lowest in winter (February 2009), particularly at Splitnose Point and The Lodge (Fig. 4). Grazing intensity on Saccharina longicruris was generally low $(<2 \%)$ and less variable across sampling periods. Grazing intensity was the highest at The Lodge and Splitnose Point for L. digitata, and at The Lodge and Cranberry Cove for S. longicruris (Fig. 4).

\section{Biological factors}

Membranipora membranacea was absent on both kelp species at Cranberry Cove and Duncan's Cove Protected during all sampling periods, and occurred in low abun-

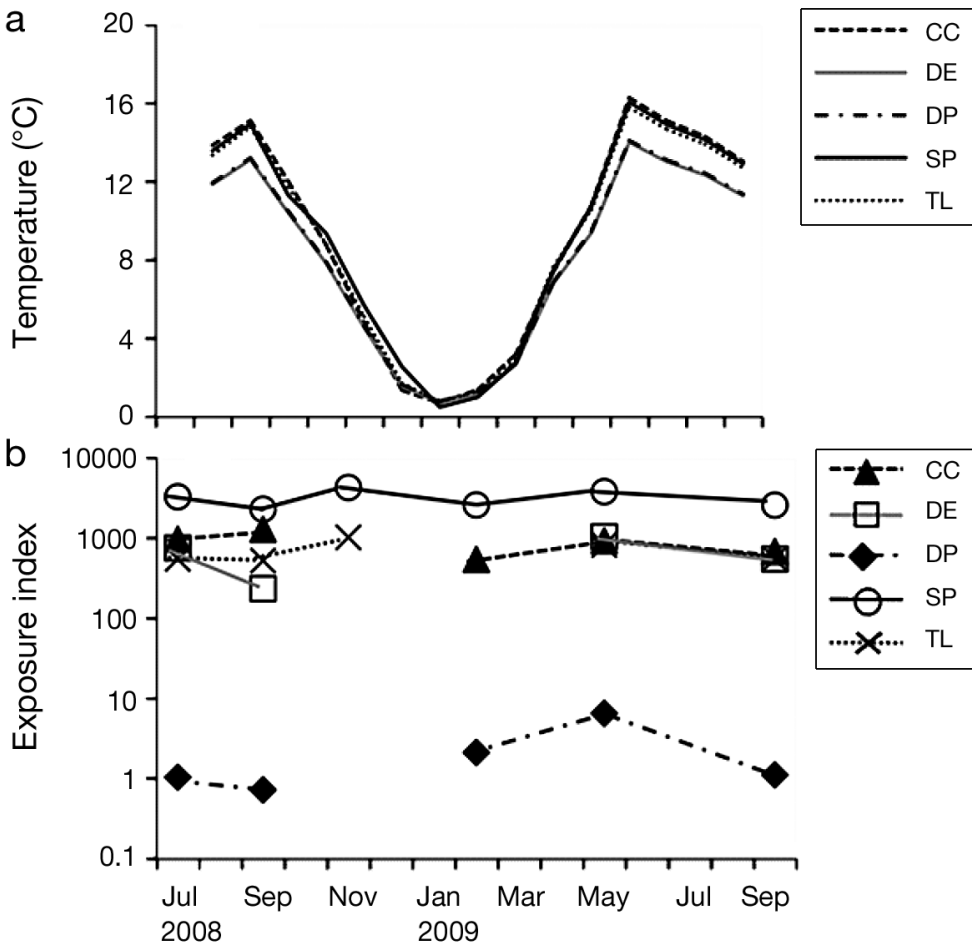

Fig. 3. (a) Average monthly temperature for the 5 sampling sites (see Fig. 1 for site abbreviations) from July 2008 to October 2009 and (b) exposure index calculated for each site during each sampling period

\section{Productivity and erosion rate}

Productivity of Saccharina longicruris followed a seasonal cycle with the highest rates of production in spring (May 2009: 0.39-14 $\mathrm{g} \mathrm{d}^{-1}$ ) and the lowest in fall and winter (November 2008: 0.08-0.10 $\mathrm{g} \mathrm{d}^{-1}$, September 2008: 0.07-0.11 $\mathrm{g} \mathrm{d}^{-1}$, February 2009: 0.02-0.09 $\mathrm{g} \mathrm{d}^{-1}$, and September 2009: 0.07-0.12 $\mathrm{g} \mathrm{d}^{-1}$ ) (Table 2, Fig. 5). Productivity differed significantly among sites around the spring peak, resulting in pronounced differences in amplitude of the seasonal cycle and a significant interaction between site and season $\left(F_{12,303}=3.96, \mathrm{p}<0.001\right)$. The highest rate was recorded at The Lodge and the lowest at Cranberry Cove, where there was little seasonal variation and productivity in summer was similar to that in spring (Table 2, Fig. 5). Productivity of Laminaria digitata followed a seasonal cycle similar to that of $S$. longicruris: rates were highest in spring (May 2009: 0.15-0.39 $\mathrm{g} \mathrm{d}^{-1}$ ) and summer (July 2008: 0.21-0.29 $\mathrm{g} \mathrm{d}^{-1}$ ) and lowest in fall (September 2008: 0.04-0.11 $\mathrm{g} \mathrm{d}^{-1}$, November 2008: 0.020.12, and September 2009: 0.04-0.16 $\mathrm{g} \mathrm{d}^{-1}$ ) (Table 2, Fig. 5). Productivity of L. digitata began to increase earlier in the year (February 2009) compared with S. longicruris (Table 2, Fig. 5). There were consistent differences in productivity among sites over time, resulting in significant effects of site $\left(F_{3,167}=29.0\right.$, p < $0.001)$ and season $\left(F_{2,167}=36.5, \mathrm{p}<0.001\right)$ with 


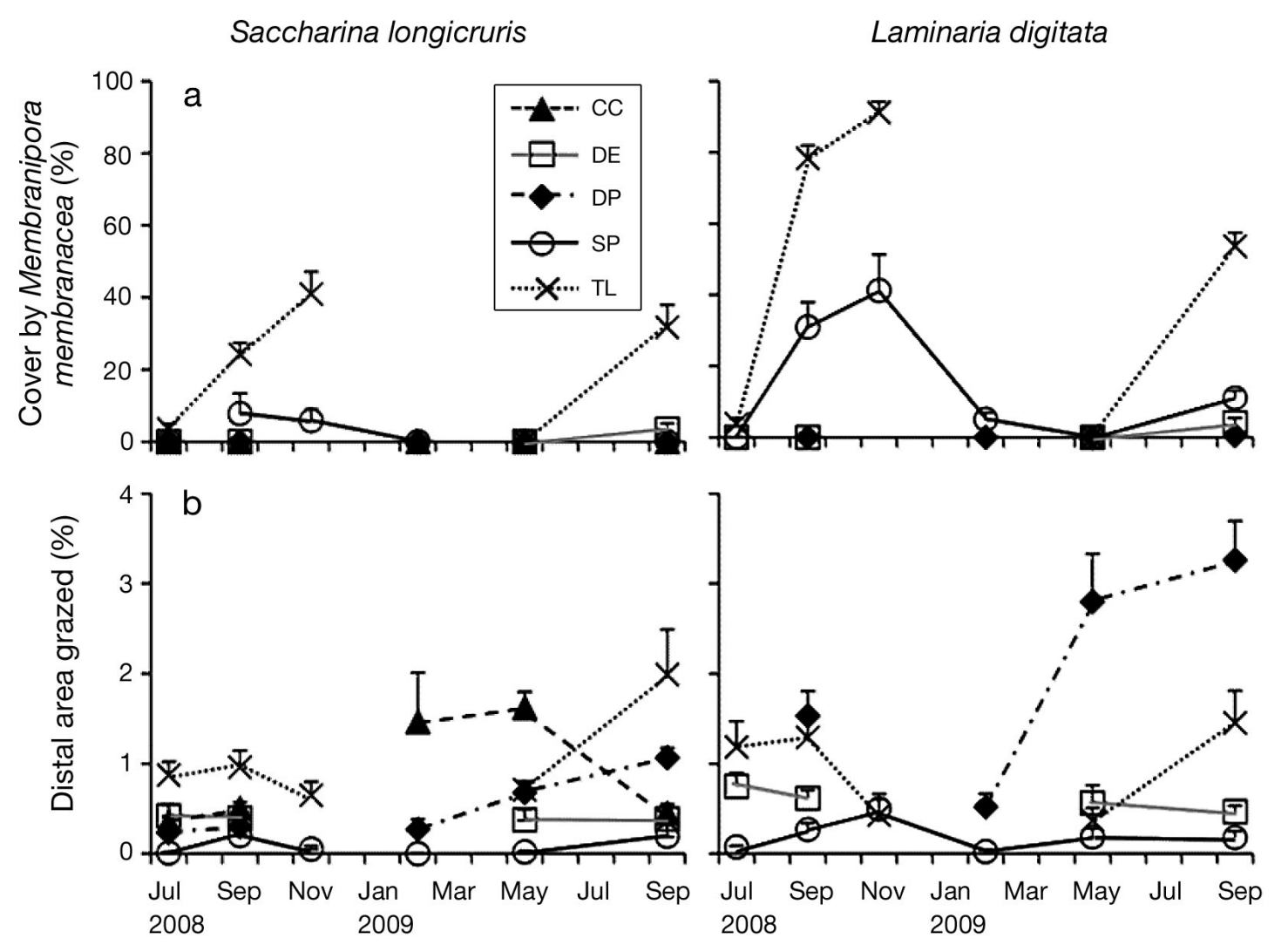

Fig. 4. Seasonal mean (+1 SE) of (a) percent cover of Membranipora membranacea and (b) percent distal area grazed for blades of Saccharina longicruris and Laminaria digitata at the 5 sampling sites (see Fig. 1 for site abbreviations). Sample size is 10 to 20 thalli during each sampling period

Table 2. One-way ANOVA of seasonal changes in erosion and productivity rates $\left(\mathrm{g} \mathrm{d}^{-1}\right)$ and the ratio of erosion to productivity $(E: P)$ for Saccharina longicruris and Laminaria digitata during 6 sampling periods (July, September and November in 2008; February, May and September in 2009) at the study sites where winter measurements were taken (CC: Cranberry Cove; DP: Duncan's Cove Protected; SP: Splitnose Point). Letters in parentheses indicate statistically significant groupings according to

Tukey's HSD tests $(\alpha<0.01)$

\begin{tabular}{|c|c|c|c|c|c|c|}
\hline Site & Variable & $\mathrm{DF}$ & SS & $F$ & $\mathrm{p}$ & Tukey's HSD \\
\hline \multicolumn{7}{|c|}{ Saccharina longicruris } \\
\hline $\mathrm{CC}$ & $\begin{array}{l}\text { Erosion } \\
\text { Productivity } \\
\text { E:P }\end{array}$ & 4 & $\begin{array}{c}0.22 \\
20.5 \\
18\end{array}$ & $\begin{array}{c}10.9 \\
20.6 \\
10\end{array}$ & $\begin{array}{l}<0.001 \\
<0.001 \\
<0.001\end{array}$ & $\begin{array}{l}\text { May(A), Sep09(AB), July(AB), Sep08(B), Feb(C) } \\
\text { July(A), May(AB), Sep09(BC), Sep08(CD), Feb(D) } \\
\text { Sep09(A), Sep08(A), May(AB), July(BC), Feb(C) }\end{array}$ \\
\hline DP & $\begin{array}{l}\text { Erosion } \\
\text { Productivity } \\
\text { E:P }\end{array}$ & 4 & $\begin{array}{l}0.13 \\
7.38 \\
10.4\end{array}$ & $\begin{array}{l}16 \\
8.35 \\
8.39\end{array}$ & $\begin{array}{l}<0.001 \\
<0.001 \\
<0.001\end{array}$ & $\begin{array}{l}\text { Sep09(A), May(A), Sep08(BC), July(B), Feb(C) } \\
\text { May(A), July(AB), Sep09(BC), Feb(BC), Sep08(C) } \\
\text { Sep09(A), Sep08(AB), May(B), July(B), Feb(B) }\end{array}$ \\
\hline SP & $\begin{array}{l}\text { Erosion } \\
\text { Productivity } \\
E: P\end{array}$ & 5 & $\begin{array}{l}0.44 \\
33.8 \\
41.1\end{array}$ & $\begin{array}{c}4.91 \\
19.6 \\
5.9\end{array}$ & $\begin{array}{r}0.001 \\
<0.001 \\
<0.001\end{array}$ & $\begin{array}{l}\operatorname{Sep} 09(A), \operatorname{July}(A B), \operatorname{Sep} 08(A B C), \operatorname{Nov}(B C), F e b(A B C), \operatorname{May}(C) \\
\text { May(A), July(A), Sep08(B), Nov(B), Sep09(B), Feb(C) } \\
\text { Feb(A), Sep09(A), Nov(AB), Sep08(AB), July(AB), May(B) }\end{array}$ \\
\hline \multicolumn{7}{|c|}{ Laminaria digitata } \\
\hline DP & $\begin{array}{l}\text { Erosion } \\
\text { Productivity } \\
\text { E:P }\end{array}$ & 3 & $\begin{array}{l}0.21 \\
6.59 \\
24.4\end{array}$ & $\begin{array}{l}7.57 \\
5.78 \\
24.4\end{array}$ & $\begin{aligned}< & 0.001 \\
& 0.002 \\
< & 0.00\end{aligned}$ & $\begin{array}{l}\text { Sep09(A), May(AB), Feb(BC), Sep08(C) } \\
\text { May(A), Feb(A), Sep09(AB), Sep(B) } \\
\text { Sep09(A), May(AB), Sep08(B), Feb(B) }\end{array}$ \\
\hline SP & $\begin{array}{l}\text { Erosion } \\
\text { Productivity } \\
\text { E:P }\end{array}$ & 5 & $\begin{array}{c}1.36 \\
22.93 \\
60.97\end{array}$ & $\begin{array}{l}3.27 \\
11.6 \\
8.12\end{array}$ & 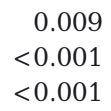 & $\begin{array}{l}\operatorname{Sep} 09(A), \operatorname{Nov}(A B), F e b(A B), \operatorname{Sep} 08(A B), J u l y(B), M a y(B) \\
\text { May(A), July(AB), Feb(ABC), Sep09(BCD), Nov(CD), Sep08(D) } \\
\text { Sep09(A), Nov(A), Sep08(A), Feb(AB), July(B), May(B) }\end{array}$ \\
\hline
\end{tabular}


no interaction between these factors $\left(F_{6,167}=4.67, \mathrm{p}=\right.$ 0.100 ). Productivity of $L$. digitata was highest at The Lodge and lowest at Duncan's Cove Protected.

Unlike productivity, erosion rates of Saccharina longicruris and Laminaria digitata varied over time with no clear seasonality or consistent differences among sites (Fig. 5), as indicated by a significant interaction between site and season for both species $(S$. longicruris: $F_{12,303}=2.29, \mathrm{p}=0.009, L$. digitata: $F_{6,167}=$ 9.25, p < 0.001). Erosion rates of $S$. longicruris were highest at The Lodge $\left(0.26-0.52 \mathrm{~g} \mathrm{~d}^{-1}\right)$ throughout the study and lowest at Cranberry Cove (0.01-0.14 $\mathrm{g} \mathrm{d}^{-1}$ ) and Duncan's Cove Protected (0.004-0.13 $\mathrm{g} \mathrm{d}^{-1}$ ) during most sampling periods (Table 2, Fig. 5). At Duncan's Cove Exposed and Splitnose Point, erosion rates in 2009 were lowest in winter (February 2009: Splitnose Point $=0.02 \mathrm{~g} \mathrm{~d}^{-1}$ ) and spring (May 2009: Duncan's Cove Exposed $=0.08$, Splitnose Point $=0.06 \mathrm{~g} \mathrm{~d}^{-1}$ ) and increased markedly by fall (September 2009: Duncan's Cove Exposed $=0.29$, Splitnose Point $=0.27 \mathrm{~g} \mathrm{~d}^{-1}$ ). Rates in fall were higher in 2009 (September) than in 2008 (September, November) at all sites, although the difference was not statistically significant at Cranberry Cove and Splitnose Point (Table 2). Erosion rates of L. digitata at Splitnose Point appeared to follow a reciprocal seasonal pattern to that of productivity, with low rates of erosion in spring (May 2009: $0.18 \mathrm{~g} \mathrm{~d}^{-1}$ ) and summer (July 2008: $0.21 \mathrm{~g} \mathrm{~d}^{-1}$ ), and high rates in fall (November 2008, September 2009: 0.39 and $0.52 \mathrm{~g} \mathrm{~d}^{-1}$, respectively) (Table 2, Fig. 5). Increases in erosion between winter/spring (February/May) and fall (September) in 2009 also were observed at The Lodge and Duncan's Cove Protected; however, erosion rate at The Lodge declined between summer (July 2008) and fall (September/November) in 2008. In contrast to other sites, erosion at Duncan's Cove Exposed was highest in spring (May 2009: $0.37 \mathrm{~g} \mathrm{~d}^{-1}$ ) and decreased markedly in fall (September 2009: $0.14 \mathrm{~g} \mathrm{~d}^{-1}$ ). Erosion rates increased significantly with total length for each kelp species when measurements were pooled across sites and seasons (L. digitata: $F_{1,260}=64.9, \mathrm{p}<0.001, \mathrm{R}^{2}=$ 0.19 , S. longicruris: $F_{1,344}=63.4, \mathrm{p}<0.001, \mathrm{R}^{2}=0.15$ ); however, this relationship explained little of the overall variance in erosion.

\section{E:P ratio}

The E:P ratio for Saccharina longicruris and Laminaria digitata showed no consistent temporal pattern across sites (Table 2, Fig. 6), and the interaction between site and season was significant for both spe-
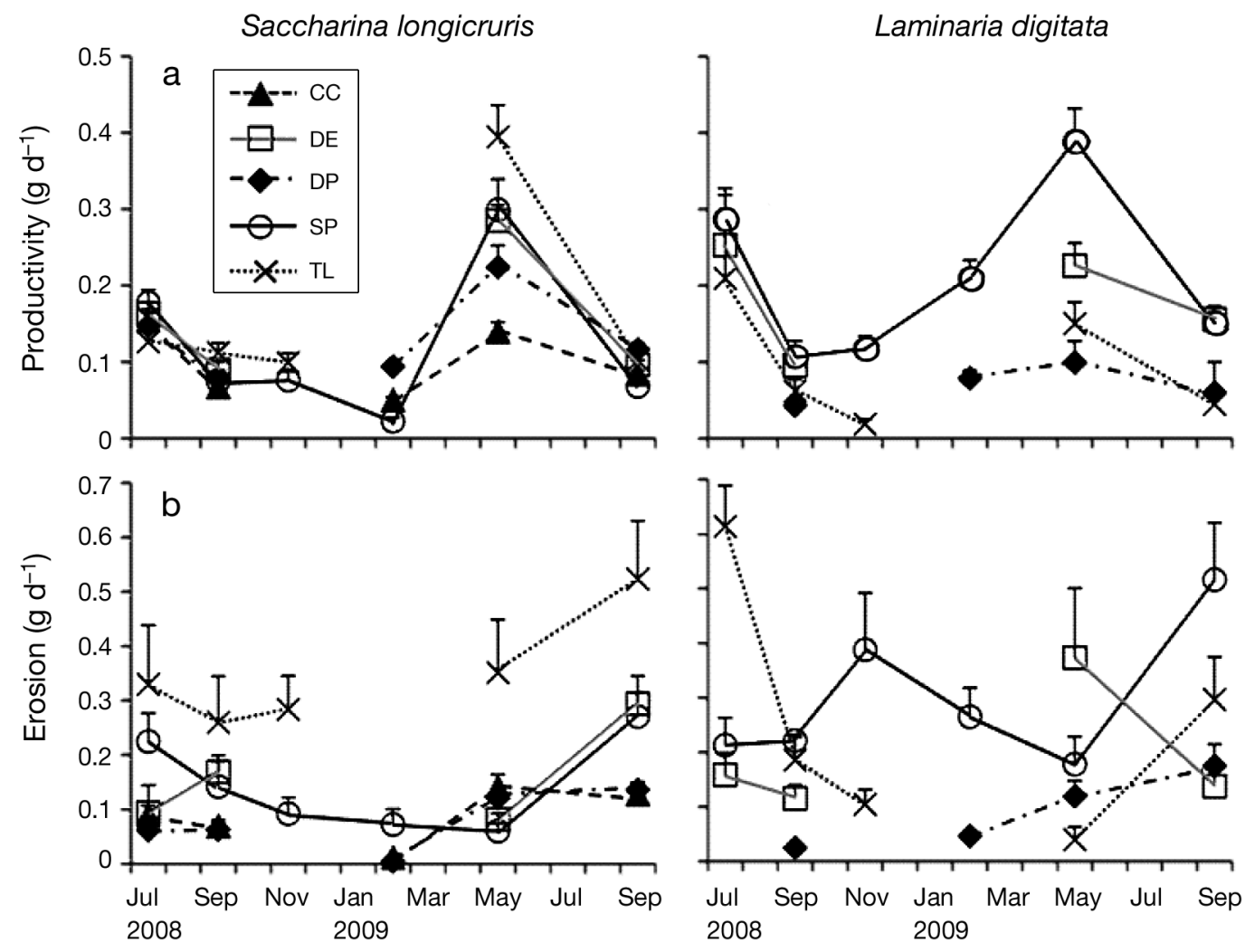

Fig. 5. Seasonal mean (+1 SE) (a) productivity and (b) erosion for Laminaria digitata and Saccharina longicruris at the 5 sampling sites (see Fig. 1 for site abbreviations). Sample size is 10 to 20 thalli during each sampling period 
cies $\left(S\right.$. longicruris: $F_{12,303}=3.96, \mathrm{p}<0.001 ;$ L. digitata: $\left.F_{6,167}=10.7, \mathrm{p}<0.001\right)$. Consistently high $E: P$ ratios were observed at The Lodge for $S$. longicruris, where biomass remained low throughout the study period. The E:P ratio was consistently at or slightly below 1 (except in February 2009) at Cranberry Cove for this species, where kelp biomass remained relatively constant across seasons (Fig. 6). The E: $P$ ratio at Duncan's Cove Exposed and Splitnose Point fluctuated widely between successive sampling periods but tended to be highest in fall (September 2008, 2009) and lowest in spring (May 2009). In 2009, a switch in the E:P ratio

a

T)

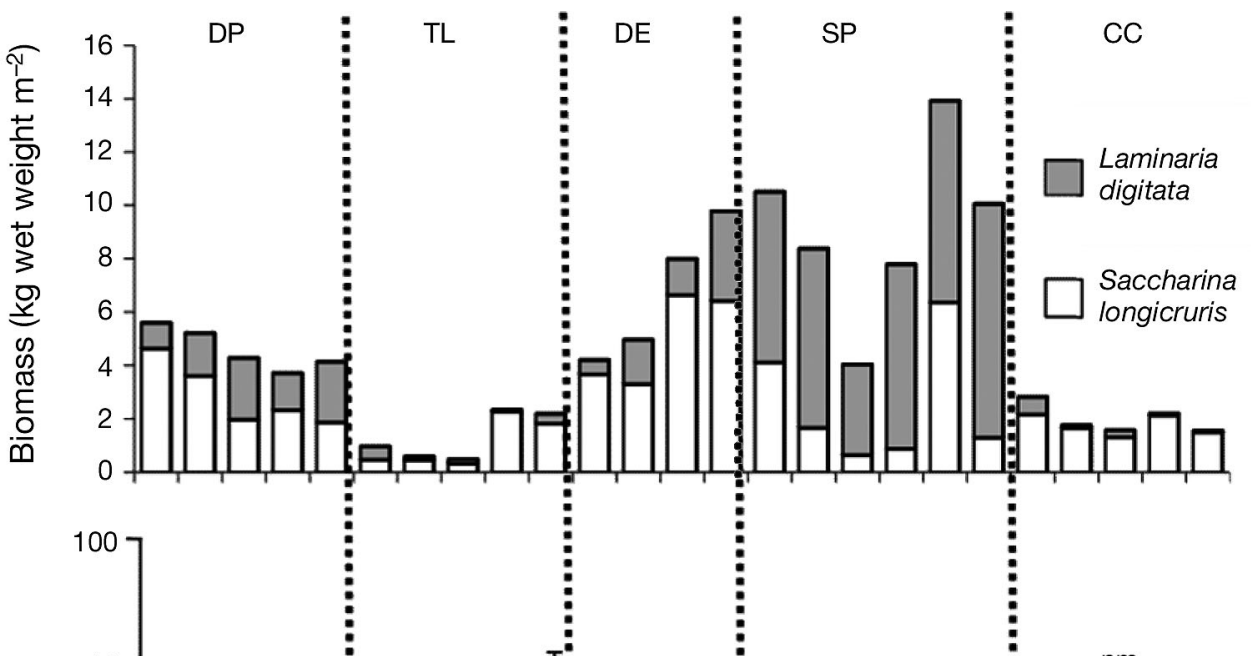

$\stackrel{0}{\dot{H}}$

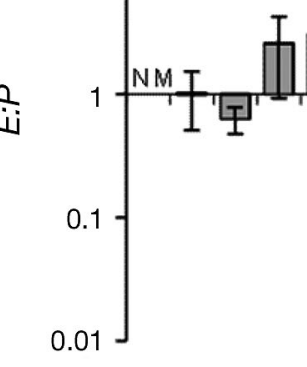

C

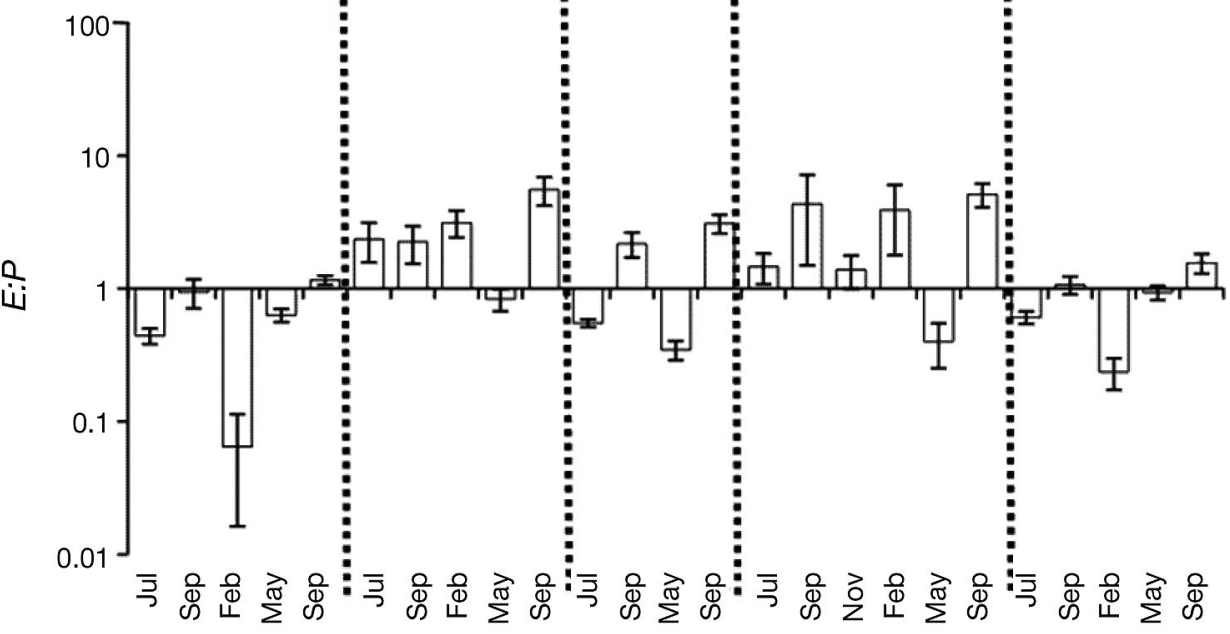

Fig. 6. (a) Mean standing biomass of Saccharina longicruris and Laminaria digitata and $(\mathrm{b}, \mathrm{c})$ the ratio of erosion to productivity $(E: P)$ at the 5 sampling sites (see Fig. 1 for site abbreviations) during all sampling periods for (b) Laminaria digitata and (c) Saccharina longicruris. E:P data are plotted on a log scale. Sample size is 10 to 20 thalli during each sampling period. 
from less than 1 in spring (May) to maximum values greater than 1 in fall (September) was associated with a marked decline in biomass of $S$. longicruris at Splitnose Point, but only slight decreases occurred at the other sites. The lowest E:P values were recorded in winter (February) at Duncan's Cove Protected and Cranberry Cove, and corresponded to small increases in biomass from winter to spring in 2009. In 2008, E:P ratios greater than 1 at The Lodge in summer and fall (July, September, November) were not associated with a decrease in biomass of $S$. longicruris during this period (Fig. 6).

For Laminaria digitata, the E:P ratio was consistently high at The Lodge (except May 2009), where biomass remained low throughout all sampling periods (Fig. 6). Conversely, the E:P ratio remained close to 1 at Duncan's Cove Exposed, corresponding to a general increase in biomass over the study period. At Splitnose Point, the E:P ratio was high in fall (September/ November 2008) and low in winter/spring (February/May 2009), corresponding to a switch from increasing to decreasing biomass around February. Increases in E: $P$ ratios between September 2008 and 2009 were observed at Duncan's Cove Protected and The Lodge, whereas the ratio remained relatively constant at Duncan's Cove Exposed and Splitnose Point over this interval (Fig. 6, Table 2).

\section{Effects of biological and physical factors on erosion rate and $E: P$ ratio}

Cover by Membranipora membranacea, distal area grazed by snails and temperature are factors (each positively related) in the best model of erosion rate of Saccharina longicruris (Tables $3 \& 4$ ). There is strong evidence that cover by $M$. membranacea is the main factor controlling this rate. Models including cover by M. membranacea were ranked as the best (ranks 1 to 5, 7 and 8) (Table S2 in the Supplement at www.intres.com/articles/suppl/m421p067_supp.pdf), and the sum of model probabilities containing this factor is high (0.91). The best model not including cover by M. membranacea had a model probability less than 0.05 . There is also evidence that temperature and percent distal area grazed are important factors driving this rate (both positively related), as the likelihood increases and the model probability is 3 times greater with the inclusion of these factors compared with the model with $M$. membranacea cover alone. Furthermore, the sum of model probabilities containing area grazed and temperature are 0.60 and 0.67 , respectively. By contrast, there is strong evidence to support exposure as the most important factor (positively related) explaining variation in erosion rate of Laminaria digitata (Tables $3 \& 4$ ), as models containing this

Table 3. The 5 best models of physical (temperature [Temp], exposure [Exp]) and biological (percent cover by Membranipora membranacea $[\% \mathrm{M}]$, percent distal area grazed by snails [\% Gzd]) factors explaining variation in erosion rate $\left(\mathrm{g} \mathrm{d}^{-1}\right)$ and the ratio of erosion to productivity $(E: P)$ for Saccharina longicruris and Laminaria digitata. Calculated are: second-order biascorrected Akaike's information criterion $\left(\mathrm{AIC}_{\mathrm{c}}\right)$, the difference between the minimum $\mathrm{AIC}_{\mathrm{c}}$ and the $\mathrm{AIC} \mathrm{C}_{\mathrm{C}}$ of each model $\left(\Delta \mathrm{AIC} \mathrm{C}_{\mathrm{c}}\right)$, the $\log$ likelihood function, the model probability $\left(w_{i}\right)$ and the $\mathrm{R}^{2}$ value of each model

\begin{tabular}{|c|c|c|c|c|c|c|}
\hline Parameter & Model & $\mathrm{AIC}_{\mathrm{c}}$ & $\Delta \mathrm{AIC}_{\mathrm{c}}$ & Log likelihood & $w_{i}$ & $\mathrm{R}^{2}$ \\
\hline \multicolumn{7}{|c|}{ Saccharina longicruris } \\
\hline \multirow[t]{5}{*}{ Erosion } & $\% \mathrm{M}+\% \mathrm{Gzd}+\mathrm{Temp}$ & -89.81 & 0.000 & 48.65 & 0.361 & 0.48 \\
\hline & $\% \mathrm{M}+\mathrm{Temp}$ & -88.41 & 1.396 & 46.56 & 0.179 & 0.40 \\
\hline & $\% \mathrm{M}+\% \mathrm{Gzd}$ & -87.79 & 2.019 & 46.25 & 0.131 & 0.38 \\
\hline & $\% \mathrm{M}$ & -87.45 & 2.353 & 44.84 & 0.111 & 0.33 \\
\hline & $\% \mathrm{M}+\operatorname{Exp}+\mathrm{Temp}$ & -85.99 & 3.818 & 46.74 & 0.053 & 0.37 \\
\hline \multirow[t]{5}{*}{ E:P } & $\% \mathrm{M}$ & 15.34 & 0.000 & -6.561 & 0.311 & 0.31 \\
\hline & $\% \mathrm{M}+\operatorname{Exp}$ & 16.48 & 1.140 & -5.889 & 0.176 & 0.32 \\
\hline & $\% \mathrm{M}+\operatorname{Exp}+$ Temp & 16.55 & 1.209 & -4.527 & 0.170 & 0.30 \\
\hline & $\% \mathrm{M}+$ Temp & 17.25 & 1.902 & -6.270 & 0.120 & 0.29 \\
\hline & $\% \mathrm{M}+\% \mathrm{Gzd}$ & 17.57 & 2.230 & -6.434 & 0.102 & 0.28 \\
\hline \multicolumn{7}{|c|}{ Laminaria digitata } \\
\hline \multirow[t]{5}{*}{ Erosion } & $\%$ Gzd + Exp & -68.17 & 0.000 & 36.54 & 0.284 & 0.41 \\
\hline & Exp & -68.03 & 0.132 & 35.16 & 0.266 & 0.35 \\
\hline & $\% \mathrm{M}+\operatorname{Exp}$ & -66.25 & 1.914 & 35.59 & 0.109 & 0.34 \\
\hline & Exp + Temp & -66.20 & 1.964 & 35.56 & 0.106 & 0.33 \\
\hline & $\% \mathrm{M}+\% \mathrm{Gzd}+\operatorname{Exp}$ & -65.74 & 2.426 & 36.87 & 0.085 & 0.39 \\
\hline \multirow[t]{5}{*}{$E: P$} & $\% \mathrm{M}+\% \mathrm{Gzd}$ & 11.52 & 0.000 & -3.300 & 0.553 & 0.72 \\
\hline & $\% \mathrm{M}+\% \mathrm{Gzd}+\operatorname{Exp}$ & 13.89 & 2.366 & -2.945 & 0.169 & 0.71 \\
\hline & $\% \mathrm{M}+\% \mathrm{Gzd}+\mathrm{Temp}$ & 14.29 & 2.768 & -3.146 & 0.139 & 0.71 \\
\hline & $\% \mathrm{M}$ & 15.95 & 4.430 & -6.834 & 0.060 & 0.60 \\
\hline & $\% \mathrm{M}+\mathrm{Temp}$ & 16.90 & 5.3742 & -5.988 & 0.038 & 0.61 \\
\hline
\end{tabular}


Table 4. Coefficient estimate and standard error for each physical (temperature [Temp], exposure [Exp]) and biological (percent cover by Membranipora membranacea [\% M], percent distal area grazed by snails [\% Gzd]) factor present in the top model according to second-order bias-corrected Akaike's information criterion $\left(\mathrm{AIC}_{\mathrm{c}}\right)$ for erosion rate $\left(\mathrm{g} \mathrm{d}^{-1}\right)$ and the ratio of erosion to productivity $(E: P)$ for Saccharina longicruris and Laminaria digitata, determined by multiple linear regression analysis

\begin{tabular}{|lclcc|}
\hline Species & Parameter & Model & Estimate & SE \\
\hline Saccharina longicruris & Erosion & $\% \mathrm{M}$ & 0.04 & 0.02 \\
& & $\% \mathrm{Gzd}$ & 0.07 & 0.04 \\
& E:P & Temp & 0.01 & 0.00 \\
& Erosion & $\% \mathrm{M}$ & 0.68 & 0.22 \\
& Eaminaria digitata & Exp & 0.06 & 0.04 \\
& & $\% \mathrm{M}$ & 0.01 & 0.00 \\
& & $\% \mathrm{Gzd}$ & 0.93 & 0.19 \\
& & & & \\
\end{tabular}

explaining variation in the $E: P$ ratio of $S$. longicruris include factors such as exposure, temperature and grazing. However, the modest increases in log-likelihood values for these models relative to the simpler, best-ranked model indicates that there is little to no evidence to suggest that these other factors are important, and the fit of these other models is determined primarily by cover of $M$. membranacea. There is also strong support for cover of $M$. membranacea as the key determinant of variation in the E:P ratio for Laminaria digitata, as this factor (positively related) also appeared in the top 5 models for this measurement (Tables $3 \& 4$ ), and the sum of model probabilities containing this factor is

factor were ranked above all those that did not, and the sum of model probabilities containing this factor is 0.95 (Table S2). Area grazed (positively related) is also present in the top model, which performed slightly better than a model without it, providing weak evidence that it may be important in determining the erosion rate of L. digitata. Models including cover by M. membranacea or temperature were also ranked as good models; however, there is little evidence to suggest that they are important factors. Comparing the log-likelihood values of these models (ranked 3 to 5) to simpler nested models indicates that the fit improved little, and that the good fit of these models is due to other variables.

Cover by Membranipora membranacea was the only factor (positively related) in the top model for the $E: P$ ratio of Saccharina longicruris (Tables $3 \& 4$ ), and the sum of model probabilities containing this factor is very high (0.95) (Table S3 in the Supplement at www.int-res.com/articles/suppl/m421p067_supp.pdf). This indicates that there is strong evidence to support $M$. membranacea as the main factor driving the $E: P$ ratio for this species. Other high-ranked models
0.99 (Table S3). There is also strong support for the role of area grazed (positively related) in E: $P$ ratio, as the model including this factor is 10 times more likely than the model with $M$. membranacea cover alone, and the sum of model probabilities containing this factor is 0.86 .

\section{Detrital production estimates}

The proportion of the total population represented by our erosion rate measurements was $>0.50$ for $S a c-$ charina longicruris at 4 of the 5 sites, and $>0.60$ for Laminaria digitata at 3 of the 4 sites where it was measured (Table 5). Individual erosion rates, averaged over all sampling periods for each species, ranged from 0.1 to $0.4 \mathrm{~g} \mathrm{~d}^{-1}$. When multiplied by the average density of the measured population, detrital production rates due to erosion range from 0.8 to $2.8 \mathrm{~g} \mathrm{~m}^{2} \mathrm{~d}^{-1}$ for $S$. longicruris and from 0.3 to $3.9 \mathrm{~g} \mathrm{~m}^{2} \mathrm{~d}^{-1}$ for L. digitata (Table 5). Combining species within kelp beds (except at Cranberry Cove, where L. digitata was rare and not measured during our study) gives estimates of annual

Table 5. Summary of measurements of Saccharina longicruris (SL) and Laminaria digitata (LD) averaged across sampling periods at each site (see Fig. 1 for abbreviations): minimum and maximum total length (TL, $\mathrm{cm}$ ) of measured individuals, density within the size range measured for erosion $\left(D_{\mathrm{M}}\right.$, ind. $\left.\mathrm{m}^{-2}\right)$, proportion of $D_{\mathrm{M}}$ relative to total density of individuals $>20 \mathrm{~cm}$ total length $\left(D_{\text {Tot }}\right)$, individual erosion rates $\left(E, \mathrm{~g} \mathrm{~d}^{-1}\right)$ and erosion rates per unit area for the measured portion of the population $\left(E_{\mathrm{M}}, \mathrm{g} \mathrm{m}^{-2} \mathrm{~d}^{-1}\right)$. Annual production of kelp detritus via erosion $\left(E_{\mathrm{MA}}, \mathrm{kg}\right.$ dry weight $\left.\mathrm{m}^{-2} \mathrm{yr}^{-1}\right)$ combines $E_{\mathrm{M}}$ for both species standardized to 1 yr. nm: not measured

\begin{tabular}{|c|c|c|c|c|c|c|c|c|c|c|c|c|c|}
\hline \multirow[t]{2}{*}{ Site } & \multicolumn{2}{|c|}{ Min TL } & \multicolumn{2}{|c|}{ Max TL } & \multicolumn{2}{|c|}{$D_{\mathrm{M}}$} & \multicolumn{2}{|c|}{$D_{\mathrm{M}} / D_{\mathrm{Tot}}$} & \multicolumn{2}{|c|}{$E$} & \multicolumn{2}{|c|}{$E_{\mathrm{M}}$} & \multirow[t]{2}{*}{$E_{\mathrm{M} A}$} \\
\hline & SL & LD & $\mathrm{SL}$ & $\mathrm{LD}$ & SL & LD & $\mathrm{SL}^{\mathrm{M}}$ & LD & SL & LD & $\mathrm{SL}$ & LD & \\
\hline $\mathrm{CC}$ & 54 & $\mathrm{~nm}$ & 172 & $\mathrm{~nm}$ & 14 & $\mathrm{~nm}$ & 0.36 & $\mathrm{~nm}$ & 0.1 & 0.0 & 1.4 & 0.0 & 0.50 \\
\hline DP & 78 & 49 & 183 & 105 & 19 & 8.8 & 0.62 & 0.29 & 0.1 & 0.1 & 1.3 & 1.0 & 0.82 \\
\hline $\mathrm{DE}$ & 110 & 68 & 247 & 170 & 16 & 6.8 & 0.65 & 0.64 & 0.2 & 0.2 & 2.8 & 1.1 & 1.43 \\
\hline TL & 81 & 42 & 185 & 105 & 5.3 & 1.3 & 0.52 & 0.75 & 0.4 & 0.3 & 1.9 & 0.3 & 0.82 \\
\hline SP & 124 & 101 & 242 & 193 & 6.1 & 13 & 0.55 & 0.67 & 0.1 & 0.3 & 0.8 & 3.9 & 1.71 \\
\hline
\end{tabular}


detrital production ranging from 0.5 to $1.71 \mathrm{~kg}$ dry weight $\mathrm{m}^{-2}$. Annual detrital production was strongly related $\left(R^{2}=0.83\right)$ to average kelp biomass across sites (Fig. 7), and was highest at Splitnose Point and lowest at Cranberry Cove.

\section{DISCUSSION}

The kelps Saccharina longicruris and Laminaria digitata exhibit a distinct annual cycle of primary productivity in the Northwest Atlantic, with a spring peak and seasonal low in late fall/winter (Mann 1972a, Chapman \& Craigie 1977, Gagné et al. 1982, Brady-Campbell et al. 1984, present study). This cycle is driven by nutrient dynamics in the water column, which in turn are linked to ocean temperature, wave action and site exposure (Chapman \& Craigie 1977, Gerard \& Mann 1979, Dobrynin et al. 2010). We detected a significant interaction between site and sampling date, indicating that seasonality in productivity is variable across sites. This variability is, in part, linked to encrustation by the invasive bryozoan Membranipora membranacea, which limits nutrient uptake by kelps (Hurd et al. 1994, 2000). This is evident in observed decreases in productivity relative to erosion (increases in E:P ratio) with increasing bryozoan cover from spring/summer to fall at Splitnose Point and The Lodge in 2008 and 2009.

Erosion rate and the E:P ratio for Saccharina longicruris and Laminaria digitata varied markedly among sites and seasons. The significant interaction of these factors indicates that seasonal patterns in erosion rate and E:P ratio differed among sites. For both measurements, positive relationships were found with percent cover by Membranipora membranacea and area grazed by snails, indicating that these factors are important determinants of spatial and temporal varia-

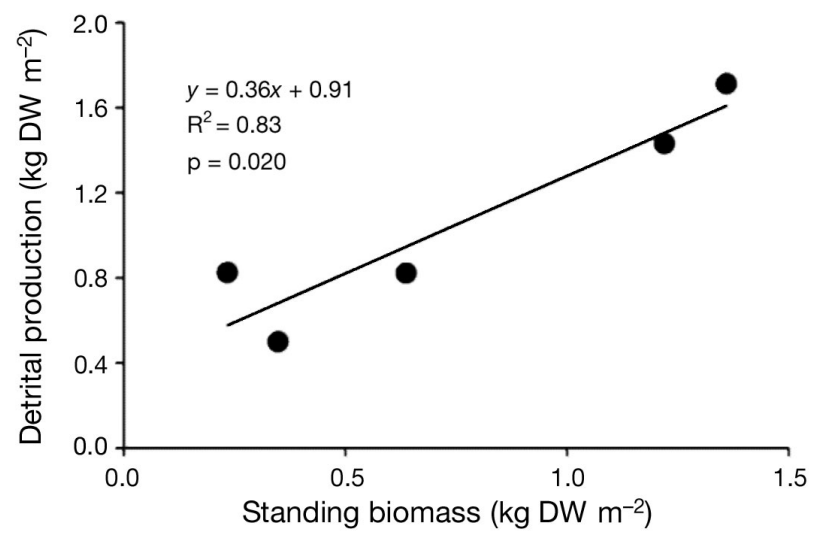

Fig. 7. The relationship between total kelp standing biomass averaged across all sampling periods at each site, and annual detrital production. DW = dry weight tion. Erosion rate and E:P ratio were highest at The Lodge and Splitnose Point, where the highest levels of encrustation by $M$. membranacea and grazing intensity were observed. Conversely, kelps were not encrusted by $M$. membranacea at Cranberry Cove and Duncan's Cove Protected, leading to low erosion rates and $E: P$ ratios at these sites. Although consistent seasonal patterns in erosion and the E: $P$ ratio were not observed, peaks in these measurements at the different sites typically corresponded to peaks in bryozoan cover or grazing intensity. For example, high bryozoan cover and grazing intensity led to high erosion rates and E:P ratios at Splitnose Point and The Lodge in summer and fall for both kelp species. At the other 3 sites, where the bryozoan was rare or absent, high erosion rates and E:P ratios were typically observed in spring during periods of high grazing intensity. Furthermore, increases in erosion rate between September 2008 and September 2009 at Duncan's Cove Protected corresponded to increases in grazing between years. Erosion was generally minimal during winter, when grazing intensity and bryozoan cover were at seasonal lows.

Extensive loss of kelp canopy following outbreaks of Membranipora membranacea has been documented in late fall/early winter in Nova Scotia and the Gulf of Maine (Berman et al. 1992, Lambert et al. 1992, Scheibling et al. 1999, Saunders \& Metaxas 2008, Scheibling \& Gagnon 2009). Encrustation by the bryozoan purportedly renders kelp blades more friable (Dixon et al. 1981), increasing susceptibility to breakage and erosion by hydrodynamic forces, although this process has not been quantified or tested explicitly. Mesograzers such as snails, which create superficial abrasions, nicks or complete perforations of blades, also can reduce the ability of kelps and other seaweeds to withstand waves, as fractures form more readily at sites of tissue damage (Black 1976, Johnson \& Mann 1986, Denny et al. 1989, Duggins et al. 2001). Although previous work has suggested that these biological factors may affect detrital production rates, our study is the first to make direct linkages between cover by M. membranacea, grazing by snails and kelp blade erosion.

Temporal and spatial variation in erosion rate also is influenced by the seasonal dynamics of temperature for Saccharina longicruris and site exposure for Laminaria digitata. Warm temperatures are linked to low nutrient levels in the water column, leading to tissue degradation in kelps (Rothäusler et al. 2009). The relationship between temperature and erosion was not observed for L. digitata, which may be attributed to differences in blade morphology between the 2 kelp species. The blade area of $S$. longicruris is typically less than that of $L$. digitata, which may result in a lower 
capacity for nutrient uptake and a stronger influence of temperature-mediated nutrient levels on erosion rate for $S$. longicruris. Erosion rates of L. digitata increased with site exposure, although this was not observed for $S$. longicruris. Again, this may be due to morphological variation between the species that is related to wave exposure. The digits of $L$. digitata were narrower and more numerous at exposed compared with protected sites, resulting in an increase in blade area with exposure (K. A. Krumhansl unpubl.). The single blade of $S$. longicruris also narrows with increasing wave exposure, but it remains broader and possibly more resistant to erosion than the highly digitate blade of $L$. digitata at wave-exposed sites. This likely leads to a greater dependence of erosion rate on wave exposure for $L$. digitata compared with $S$. longicruris.

The ratio of erosion to production is an indication of whether a kelp bed is decreasing $(E: P$ ratio $>1)$ or increasing $(<1)$ in biomass. We observed some linkages between long-term patterns in total biomass and E:Pratio; however, these relationships were not consistent. For example, the E:P ratio was consistently high at The Lodge for both Saccharina longicruris and Laminaria digitata, resulting in the lowest recorded biomass of all sites. At sites where the E:P ratio remained close to 1 (Cranberry Cove for $S$. longicruris, and Duncan's Cove Protected for L. digitata), biomass increased or remained relatively constant during the study period. We expected that biomass would increase at sites were $E: P$ ratios were consistently lower than 1, but this was not observed. Some linkages between biomass changes and E:P ratio were observed seasonally, including a decline in biomass from spring to fall at some sites for $S$. longicruris, associated with increases in the E:P ratio. However, these measurements were generally not well correlated in the short term. A clearer relationship between seasonal patterns in $E: P$ ratio and biomass may be observed if biomass changes are measured over the same sampling intervals as erosion rate.

We demonstrate that a large quantity of detritus is produced annually by erosion of particulates and larger fragments from kelp thalli. These estimates were generated for a portion of the sporophyte population (albeit the majority in most cases) and are therefore conservative. However, the degree of underestimation is likely small because our measurements are based on the larger size fraction of the population, and erosion rate is directly related to total length for both Saccharina longicruris and Laminaria digitata. Thus, larger kelps contribute a much greater proportion of the total eroded material than individuals below our minimum size limit for measurement (30-40 cm total length). Another component of detrital production from subtidal kelp beds is the loss of large sections of blade, or dislodgement of whole thalli, that occurs during major storm events, such as passing hurricanes. Massive pulses of detrital material can be exported from kelp beds to adjacent intertidal and subtidal habitats during these sporadic events (authors' unpubl. data), substantially augmenting the more gradual and continuous erosion and fragmentation of blade tissue measured in our study.

The amount of detrital material produced annually from erosion of both Saccharina longicruris and Laminaria digitata ranged from 0.5 to $1.7 \mathrm{~kg}$ dry weight $\mathrm{m}^{-2}$ across sites. This is equivalent to 150 to $513 \mathrm{~g} \mathrm{C} \mathrm{m}^{-2}$, as carbon composes $30 \%$ of blade tissue for both kelp species (Mann 1972b). These values equal or exceed those recorded for phytoplankton production off the Atlantic coast of Nova Scotia, estimated at $190 \mathrm{~g} \mathrm{C} \mathrm{m}^{-2}$ (Platt 1971), indicating that particulate kelp detritus may be the main source of food for suspension- and deposit-feeders in deep-water communities in this region. Our estimates of detrital production in Nova Scotian kelp beds also exceed those recorded for seagrass beds in North America, which range from 4 to $135 \mathrm{~g} \mathrm{C} \mathrm{m}^{-2}$ (reviewed by Heck et al. 2008).

We found a positive relationship between the amount of material eroded annually and standing biomass. Long-term reductions in kelp biomass have been linked to encrustation of kelps by Membranipora membranacea (Scheibling \& Gagnon 2006, 2009). At The Lodge, a $40 \%$ decline in canopy cover was documented 2 yr prior to our study (Saunders \& Metaxas 2008), and biomass remained low throughout the study. Therefore, although $M$. membranacea may increase the amount of material eroded from kelps in the short term, long-term decreases in kelp biomass due to bryozoan encrustation may ultimately lead to a decline in detrital production in kelp beds.

We have shown that a combination of environmental and biological factors affects rates of erosion and the ratio of erosion to productivity of kelps along the Atlantic coast of Nova Scotia, which in turn influence the dynamics of detrital export to surrounding habitats. These rates will be affected by ongoing changes in ocean climate and anthropogenic disturbances, such as species introductions. For example, a positive effect of temperature on erosion rate indicates that warming can lead to changes in detrital production. We also have shown that encrustation by the invasive bryozoan Membranipora membranacea alters detrital production rates by increasing erosion rates relative to productivity in both Saccharina longicruris and Laminaria digitata. This non-consumptive interaction between a native alga and an invasive bryozoan provides a striking example of an indirect effect of an introduced species on energy export from kelp beds.

The exchange of detrital material may be a significant form of connectivity between subtidal kelp beds 
and adjacent, less-productive areas. Therefore, changes in rates of detrital production and export from kelp beds are likely to have important consequences for deep-water assemblages that rely on algal detritus as an energy source. Previous studies have demonstrated these effects in other systems, including effects of species introductions. For example, changes in amphipod assemblages have been attributed to increased detrital accumulation in areas invaded by the green alga Caulerpa racemosa in the Mediterranean (VazquezLuis et al. 2008). Similar effects have been observed in terrestrial ecosystems where detritus from non-native species may alter soil conditions and/or food availability (Wolkovich et al. 2009). Ultimately, understanding the roles of environmental and biological factors in the dynamics of detrital export from kelp beds will aid in predicting impacts of human-mediated changes to climate and habitat on the structure and function of coastal ecosystems.

Acknowledgements. We thank J. Lindley, L. Sauchyn, S. Watanabe, D. Lyons, V. Burdett Coutts, A. Yorke, M. Saunders, R. Daigle, M. Lloyd, A. McCurdy, T. Wilson and A. Ryan for field assistance. We also thank D. Lyons, J.-S. Lauzon-Guay, M. Saunders, A. Metaxas and H. Lotze for statistical advice and comments on earlier drafts of the manuscript, and D. Duggins and 2 anonymous reviewers for comments on the submitted manuscript. This research was funded by a Discovery Grant and a Strategic Networks Grant (Canadian Healthy Oceans Network) to R.E.S. from the Natural Sciences and Engineering Research Council (NSERC) of Canada. K.A.K. was supported by a Dalhousie University Scholarship.

\section{LITERATURE CITED}

Anderson DR (2008) Model based inference in the life sciences: a primer on evidence. Springer, New York, NY

Balch T, Scheibling RE (2000) Temporal and spatial variability in settlement and recruitment of echinoderms in kelp beds and barrens in Nova Scotia. Mar Ecol Prog Ser 205: $139-154$

Berman J, Harris L, Lambert W, Buttrick M, Dufresne M (1992) Recent invasions of the Gulf of Maine: three contrasting ecological histories. Conserv Biol 6:435-441

Black R (1976) The effects of grazing by the limpet Acmaea insessa on the kelp Egregia laevigata in the intertidal zone. Ecology 57:265-277

Brady-Campbell MM, Campbell DB, Harlin MM (1984) Productivity of kelp (Laminaria spp.) near the southern limit in the Northwestern Atlantic Ocean. Mar Ecol Prog Ser 18:79-88

Bustamante RH, Branch GM (1996) The dependence of intertidal consumers on kelp-derived organic matter on the west coast of South Africa. J Exp Mar Biol Ecol 196: $1-28$

Bustamante RH, Branch GM, Eekhout S (1995) Maintenance of an exceptional intertidal grazer biomass in South Africa: subsidy by subtidal kelps. Ecology 76:2314-2329

Chapman ARO (1981) Stability of sea urchin dominated barren grounds following destructive grazing of kelp in St. Margret's Bay, Eastern Canada. Mar Biol 62:307-311
Chapman ARO, Craigie JS (1977) Seasonal growth in Laminaria longicruris: relations with dissolved inorganic nutrients and internal reserves of nitrogen. Mar Biol 40: 197-205

> Denny M, Brown V, Carrington E, Kraemer G, Miller A (1989) Fracture mechanics and the survival of wave-swept macroalgae. J Exp Mar Biol Ecol 127:211-228

Dixon J, Schroeter SC, Kastendiek J (1981) Effects of the encrusting bryozoan Membranipora membranacea on the loss of blades and fronds by the giant kelp, Macrocystis pyrifera (Laminariales). J Phycol 17:341-345

> Dobrynin M, Gayer G, Pleskachevsky A, Gunther H (2010) Effect of waves and currents on the dynamics and seasonal variations of suspended particulate matter in the North Sea. J Mar Syst 82:1-20

$>$ Duggins DO, Simenstad CA, Estes JA (1989) Magnification of secondary production by kelp detritus in coastal marine ecosystems. Science 245:170-173

Duggins D, Eckman JE, Siddon CE, Klinger T (2001) Interactive roles of mesograzers and current flow in survival of kelps. Mar Ecol Prog Ser 223:143-155

- Eastwood MM, Donahue MJ, Fowler AE (2007) Reconstructing past biological invasions: niche shifts in response to invasive predators and competitors. Biol Invasions 9: 397-407

> Gagné JA, Mann KH, Chapman ARO (1982) Seasonal patterns of growth and storage in Laminaria longicruris in relation to differing patterns of availability of nitrogen in the water. Mar Biol 69:91-101

> Galil BS (2007) Loss or gain? Invasive aliens and biodiversity in the Mediterranean Sea. Mar Pollut Bull 55:314-322

> Gerard VA, Mann KH (1979) Growth and production of Laminaria longicruris (Phaeophyta) populations exposed to different intensities of water movement. J Phycol 15:33-41

> Hart RE, Evans JL (2001) A climatology of the extratropical transition of Atlantic tropical cyclones. J Clim 14:546-564

> Hatcher BG, Chapman ARO, Mann KH (1977) An annual carbon budget for the kelp Laminaria longicruris. Mar Biol 44:85-96

> Heck KL, Carruthers TJB, Duarte CM, Hughes AR, Kendrick G, Orth RJ, Williams SW (2008) Trophic transfers from seagrass meadows subsidize diverse marine and terrestrial consumers. Ecosystems 11:1198-1210

> Hurd CL, Durante KM, Chia FS, Harrison PJ (1994) Effect of bryozoan colonization on inorganic nitrogen acquisition by kelps Agarum fimbratum and Macrocystis integrifolia. Mar Biol 121:167-173

- Hurd CL, Durante KM, Harrison PJ (2000) Influence of bryozoan colonization on the physiology of the kelp Macrocysis integrifolia (Laminariales, Phaeophyta) from nitrogen-rich and -poor sites in Barkley Sound, British Columbia. Phycologia 39:435-440

> Huxel GR, McCann K (1998) Food web stability: the influence of trophic flows across habitats. Am Nat 152:460-469

> Hyndes GA, Lavery PS (2005) Does transported seagrass provide an important trophic link in unvegetated nearshore habitats? Estuar Coast Shelf Sci 63:633-643

> Johnson CR, Mann KH (1986) The importance of plant defense abilities to the structure of subtidal seaweed communities: the kelp Laminaria longicruris de la Pylaie survives grazing by the snail Lacuna vincta (Montagu) at high populations densities. J Exp Mar Biol Ecol 97: 231-267

- Keddy PA (1982) Quantifying within-lake gradients of wave energy: interrelationships of wave energy, substrate particle size and shoreline plants in Axe Lake, Ontario. Aquat Bot 14:41-58

Kenchington ELR, Gilkinson KD, MacIsaac KG, Bourbonnais- 
Boyce C, Kenchington TJ, Smith SJ, Gordon DC (2006) Effects of experimental otter trawling on benthic assemblages on Western Bank, northwest Atlantic Ocean. J Sea Res 56:249-270

Knip DM, Scheibling RE (2007) Invertebrate fauna associated with kelp enhances reproductive output of the green sea urchin Strongylocentrotus droebachiensis. J Exp Mar Biol Ecol 351:150-159

Lambert WJ, Levin PS, Berman J (1992) Changes in the structure of a New England (USA) kelp bed: The effects of an introduced species? Mar Ecol Prog Ser 88:303-307

Lauzon-Guay JS, Scheibling RE (2007) Seasonal variation in movement, aggregation and destructive grazing of the green sea urchin (Strongylocentrotus droebachiensis) in relation to wave action and sea temperature. Mar Biol 151:2109-2118

Lawson GS, Tyler PS, Young CM (1993) Attraction of deepsea amphipods to macrophyte food falls. J Exp Mar Biol Ecol 128:165-176

Lenanton RCJ, Robertson AI, Hansen JA (1982) Nearshore accumulations of detached macrophytes as nursery areas for fish. Mar Ecol Prog Ser 9:51-57

Lundberg J, Moberg F (2003) Mobile link organisms and ecosystem functioning: implications for ecosystem resilience and management. Ecosystems 6:87-98

Lipcius RN, Eggleston DB, Schreiber SJ, Seitz RD and others (2008) Importance of metapopulation connectivity to restocking and restoration of marine species. Rev Fish Sci 16:101-110

Mann KH (1972a) Ecological energetics of the seaweed zone in a marine bay on the Atlantic coast of Canada. II. Productivity of the seaweeds. Mar Biol 14:199-209

Mann KH (1972b) Ecological energetics of the seaweed zone in a marine bay on the Atlantic Coast of Canada. I. Zonation and biomass of seaweeds. Mar Biol 12:1-10

Mann KH (1982) Kelp, sea urchins and predators: a review of strong interactions in rocky subtidal systems of eastern Canada. J Sea Res 16:414-423

Miller RJ (1985) Succession in sea urchin and seaweed abundance in Nova Scotia, Canada. Mar Biol 84:275-286

- Nakano S, Murakami M (2001) Reciprocal subsidies: dynamic interdependence between terrestrial and aquatic food webs. Proc Natl Acad Sci USA 98:166-170

Newell RC, Field JG, Griffiths CL (1982) Energy balance and significance of microorganisms in a kelp bed community. Mar Ecol Prog Ser 8:103-113

Orr M, Zimmer M, Jelinski DE, Mews M (2005) Wrack deposition on different beach types: spatial and temporal variation in the pattern of subsidy. Ecology 86:1496-1507

Platt T (1971) The annual production by phytoplankton in St. Margaret's Bay, Nova Scotia. J Cons Int Explor Mer 33:324-333

Polis GA, Hurd SD (1996) Linking marine and terrestrial food webs: allochthonous input from the ocean supports high secondary productivity on small islands and coastal land communities. Am Nat 147:396-423

- Polis GA, Anderson WB, Holt RD (1997) Toward an integra-

Editorial responsibility: Hans Heinrich Janssen, Oldendorf/Luhe, Germany tion of landscape and food web ecology: the dynamics of spatially subsidized food webs. Annu Rev Ecol Syst 28: 289-316

> Rothäusler E, Gómez I, Hinojosa IA, Karsten U, Tala F, Thiel M (2009) Effect of temperature and grazing on growth and reproduction of floating Macrocystis spp. (Phaeophyceae) along a latitudinal gradient. J Phycol 45:547-559

- Saunders M, Metaxas A (2008) High recruitment of the introduced bryozoan Membranipora membranacea is associated with kelp bed defoliation in Nova Scotia, Canada. Mar Ecol Prog Ser 369:139-151

Schaffelke B, Hewitt CL (2007) Impacts of introduced seaweeds. Bot Mar 50:397-417

Scheibling RE, Gagnon P (2006) Competitive interactions between the invasive green alga Codium fragile ssp. tomentosoides and native canopy-forming seaweeds in Nova Scotia (Canada). Mar Ecol Prog Ser 325:1-14

Scheibling RE, Gagnon P (2009) Temperature-mediated outbreak dynamics of the invasive bryozoan Menbranipora membranacea in Nova Scotian kelp beds. Mar Ecol Prog Ser 390:1-13

Scheibling RE, Hennigar AW, Balch T (1999) Destructive grazing, epiphytism, and disease: the dynamics of sea urchin-kelp interactions in Nova Scotia. Can J Fish Aquat Sci 56:2300-2314

Smith BD (1988) Comparison of productivity estimates for Laminaria in Nova Scotia. Can J Fish Aquat Sci 45: $557-562$

> Sorte CJB, Williams SL, Carlton JT (2010) Marine range shifts and species introductions: comparative spread rates and community impacts. Glob Ecol Biogeogr 19:303-316

Tala F, Edding M (2005) Growth and loss of distal tissue in blades of Lessonia nigrescens and Lessonia trabeculata (Laminariales). Aquat Bot 82:39-54

Thomsen MS, Wernberg T, Tuya F, Silliman BR (2009) Evidence for impacts of nonindigenous macroalgae: a metaanalysis of experimental field studies. J Phycol 45:812-819

- Van den Poel D, Lariviere B (2004) Customer attrition analysis for financial services using proportional hazard models. Eur J Oper Res 157:196-217

> Vazquez-Luis M, Sanchez-Jerez P, Bayle-Sempere JT (2008) Changes in amphipod (Crustacea) assemblages associated with shallow-water algal habitats invaded by Caulerpa racemosa var. cylindracea in the western Mediterranean Sea. Mar Environ Res 65:416-426

- Vetter EW (1995) Detritus-based patches of high secondary production in the nearshore benthos. Mar Ecol Prog Ser 120:251-262

Vetter EW (1998) Population dynamics of a dense assemblage of marine detritivores. J Exp Mar Biol Ecol 226:131-161

Vetter EW, Dayton PK (1999) Organic enrichment by macrophyte detritus, and abundance patterns of megafaunal populations in submarine canyons. Mar Ecol Prog Ser 186: $137-148$

Wolkovich EM, Bolger DT, Holway DA (2009) Complex responses to invasive grass litter by ground arthropods in a Mediterranean scrub ecosystem. Oecologia 161:697-708

Submitted: August 27, 2010; Accepted: October 27, 2010

Proofs received from author(s): December 18, 2010 